\title{
UMÍRÁNÍ A SMRT V HISTORICKÉM VÝVOJI
}

\author{
Helena Kisvetrová1, Jana Kutnohorská ${ }^{2}$ \\ ISSN 1212-4117 \\ ${ }^{1}$ Univerzita Palackého v Olomouci, Fakulta zdravotnických věd, Ústav ošetřovatelství \\ 2Univerzita Palackého v Olomouci, Fakulta zdravotnických věd, Ústav společenských a humanitních věd
}

12: 212-219, 2010

\section{ÚVOD}

Smrt je předmětem trvalého zájmu každé kultury v historickém vývoji po celém světě. Je středem zájmu filozofie bytí od jejího počátku do současnosti. Každá civilizace a každé společenství řeši otázky spojené s umíráním i smrtí a spojuje je s celou škálou různých rituálů, které se v jednotlivých civilizacích výrazně odlišují a vypovídají o kultuře společnosti. Péče o terminálně nemocné a umírající v širokém pojetí patří $\mathrm{k}$ základním principům lékařské, ošetřovatelské i sociální péče. Vyspělost kultury každé společnosti můžeme hodnotit i podle toho, jak se dokáže postarat o své umírající členy.

\section{Změny postoje ke smrti v průběhu lidských dějin}

Většina rituálů jednotlivých civilizací v celé historii lidstva měla povahu udržovací. Jejich úkolem bylo zachovat, potvrdit a zabezpečit stávající stav. Vývoj postoje ke smrti a s tím související rituály a obřady se řídily jednoduchými proměnami čtyř psychologických prvků (Ariès, 2000b, s. 370): vědomí sebe sama, obrana společnosti proti divokosti prírody, víra $\mathrm{v}$ posmrtný život a víra v existenci zla. Postoje ke smrti, ošetřování umírajících a s tím spojené rituály, které se $\mathrm{v}$ průběhu lidských dějin měnily a vyvijely, tak jako se měnila a vyvijela lidská společnost, lze shrnout do pěti modelů smrti:

1) „Ochočená smrt", nejstarší model smrti, kdy smrt nebyla osobní tragédií, ale zkouškou společenství, jehož úkolem bylo zabezpečení kontinuity druhu.

2) „Smrt sebe samého“, model se objevuje v 11. století a posouvá osud směrem k člověku. Smrt lidé začínají považovat za osobní a poslední drama jedince.

3) „Smrt vzdálená i blízká“", lidé se začali přibližovat $\mathrm{k}$ té podobě smrti, která jim byla dosud vzdálená.
4) „Smrt blízkého“, objevuje se v 19. století a mění pohled lidí na smrt. Pozůstalí se vyrovnávali se smrtí blízké osoby obtížněji než dř́ve. Neobávali se vlastní smrti, ale smrti druhého. Tento fenomén stojí na počátku zrodu moderního funerálního kultu hrobů a hřbitovů.

5) „Převrácená smrt“, objevuje se ve 20. století, kdy se mění postoj lidí ke smrti. Tabuizace, institucionalizace, deritualizace a oddalování smrti se stávají projevem selhání společnosti v postoji ke smrti i péči o umírající (Ariès, 2000b, s. 370-379).

\section{Starověk}

Postoj ke smrti a mrtvým ve starověkých civilizacích a kulturách byl významně determinován jejich vztahem $\mathrm{k}$ bohům. Výsledkem byly diametrálně odlišné postoje k umírajícím i samotné smrti v jednotlivých kulturách, jak můžeme sledovat na príkladech egyptských, perských a skytských pohřebních rituálů i biblického pojetí u židovského národa.

\section{Egypt}

Ve starém Egyptě už v prehistorickém období existovaly velmi přesné pohřební obřady, a to i u chudších vrstev obyvatelstva. Každá rodina z vesnice nebo z jejího bezprostředního okolí tehdy buduje pro své zemřelé skromné hroby. Mrtví rodiče tak zůstávají $\mathrm{v}$ úzkém spojení s živými, jedí s nimi a oslavují svátky. V prostých vyhloubených jámách je mrtvý uložen v embryonální poloze jako nový zárodek $\mathrm{v}$ útrobách země, připravený pomocí magie ke znovuzrození; nahé tělo obvykle leželo na pravém boku, obličej obrácený $\mathrm{k}$ západu, říši mrtvých, odkazu na každodenní mizení slunce na západě. Vedle těl nebožtíků byly uloženy prosté obětiny určené $\mathrm{k}$ jejich obživě i okrase: obilná zrna (vedle úst nebo $\mathrm{v}$ nádobě), pštrosí vejce, ryby, perly, peř́, občas kytice květů u hrudi, 
symbol rostlinného znovuzrození, jehož přítomnost měla podle magie forem nevyhnutelně přivodit znovuzrození mrtvého. Jáma mohla být zakryta hromadou vápencových kamenů všech velikostí, vytvářejících mírný pahorek, první primitivní architekturu. Tyto skutečnosti jsou rovněž důkazem existence náboženské magie, základu rituálu vykonávaného podél celého Nilu. Jsou svědectvím první duchovní pospolitosti obyvatel Nilského údolí (Lalouettová, 2009, s. 12-13).

Uctívání předků a s tím spojený kult mrtvých byl významnou součástí egyptského života. Egypt'ané věřili, že smrt neznamená zničení lidské bytosti, ale jen její přechod do jiného světa. Ten si představovali jako fantasticky pozměněný pozemský svět, ve kterém pak žil zemřelý v podobě ducha. Jejich pozemský život byl chápán jako pŕíprava na přechod do jiného světa, do toho po smrti. Dokladem jsou egyptské pyramidy a přemrštěný rozvoj kultu pohřbívání včetně propracovaného systému balzamování zemřelých (Blumenthal-Barby, 1987, s. 1213). Pozůstalí odnesli zemřelého $\mathrm{k}$ balzamovačủm, kteř́ jim nabídli různě nákladné varianty. Při nejdražším způsobu balzamování odstranili nejprve mozek přes nosní otvory, otevřeli břišní dutinu a vyňali vnitřnosti. Pak břišní dutinu vypláchli palmovým vínem a znovu vyčistili. Břicho naplnili utřenou myrtou a dalším kořením, zašili a tělo naložili na 70 dnů do sodného louhu. Po této době celé tělo umyli, zabalili do pruhů plátna a natřeli klovatinou. Takto připravené tělo odevzdali př́buzným, kteří je vložili do dřevěné rakve v podobě člověka a uložili do pohřební komory. U levnějších způsobů balzamování neodstraňovali balzamovači vnitřnosti, ale střeva naplnili cedrovým olejem. Po stanovené době olej včetně rozpuštěných vnitřností vypustili, pak namočili tělo do sodného louhu, aby se odstranilo maso a z mrtvoly zůstala jen kůže a kosti. Bez jakýchkoliv dalších úprav tělo předali pozůstalým (Hérodotos, 1972, s. 127-128). Pečlivé uchovávání mrtvol (mumifikace), chrámy mrtvých a obrovské pyramidy dokazují, že staři Egypt'ané mysleli více na svůj život po smrti než na život pozemský a prožívali úzkost z toho, aby se na smrt a přechod do posmrtného života dokázali co nejlépe pripravit. Nebýt pohřben bylo považováno ve starém Egyptě za největší potupu, jak ukazuje nápis na jedné stéle: „Pro toho, kdo se vzbouří proti Jeho Veličenstvu, není hrobky a jeho mrtvola bude vhozena do řeky“ (Lalouettová, 2009, s. 203).

Abdel-Khalek a Tomás-Sábado (2005, s. 157-167) ve své studii „Anxiety and Death Anxiety in Egyptian and Spanish Nursing Students" zkoumali problematiku úzkosti ze smrti u současné populace egyptských studentů a zjistili, že jednou z determinant strachu ze smrti byl i odkaz kultury starověkého Egypta.

\section{Persie}

Protikladem staroegyptského kultu jsou rituály starověké Persie. Velkou úlohu zde hrál oheň, symbol čistoty. Ta mizela při styku člověka nebo věcí se zdrojem nečistoty, zejména s mrtvým tělem. Proto byly nařizovány velmi důkladné očišt'ovací ceremonie spojené s péči o umírajícího, zemřelého i o jeho pečovatele. Především omývání vodou a kravskou močí, o které se věřilo, že má zázračné účinky. Mrtvoly se nesměly ani spalovat ani zakopávat do země, aby neposkvinily svaté živly, ale byly umístěny do ohrazených prostor (mrchovišt'), kde byly vydány na pospas supům. Jen čisté kosti se pak ukládaly do země (Klíma, 1977, s. 29-30). Dokonce i mrtvoly vážených osobností byly umist’ovány na tzv. mrchoviště. Také Hérodotos (1972, s. 73) se ve svých Dějinách zmiňuje o tom, že když Peršan zemře, nepohřbí nikdo jeho mrtvé tělo dřive, dokud není okousáno od dravých ptáků nebo psů. Lze předpokládat, že tento kult neprispíval $\mathrm{k}$ pozitivnímu chápání smrti, protože řriše smrti byla považována za rríši zlého ducha Angra Mainyu (Blumenthal-Barby, 1987, s. 13). Zemřelý - zdroj nečistoty pro živé - tak vyvolával spíš hrůzu a odpor než úctu a zármutek pozůstalých.

\section{Skytové}

Skytové byli těsně spjati s řeckým světem. Tento významný starověký národ, který se rozvíjel v 8. až 2. století př. n. 1., se podílel na šíření řecké kultury na území východní Evropy a vytvořil zde vyspělou kulturu. Bez nadsázky lze říci, že $\mathrm{v}$ dějinách evropské civilizace následují za Řeky a Rímany Skytové a Keltové (Smirnov, 1980, s. 7-8).

Pohřební skytské rituály spojené s úmrtím krále zmiňuje i Hérodotos ve svých Dějinách (1976, s. 245-247). Z těla zemřelého krále byly odstraněny vnitřnosti a břišní dutina byla napl- 
něna utlučeným kořením, vonnými látkami, petrželovým semínkem a koprem. Celé tělo pak bylo potaženo voskem. Takto upravenou mrtvolu královští služebníci přepravovali na voze k jednotlivým národům, kterým král vládl. $\mathrm{Na}$ konec královo tělo uložili do hrobu na lůžko ze slámy. Spolu s králem pohřbili i lidské oběti, prvotiny všech plodů a zlaté číše. Nad hrobem pak nasypali velkou mohylu. Po roce od úmrtí krále obětovali na jeho hrobě 50 nejvěrnějších králových služebníků. Pokud zemřel jiný člen skytského národa, naložili nejbližší prúbuzní podobně upravené mrtvé tělo na vưz a objížděli s ním prátele. Rodiny prátel pohostily smuteční doprovod všemi druhy jídla a stejné dary pokládaly i na vưz se zemřelým. Takto Skytové vozili zemřelého čtyřicet dní a teprve pak ho pohřbili. Po pohřbu se obřadně očišt'ovali (Hérodotos, 1972, s. 247).

\section{Řecko}

Také v řeckých dějinách nalézáme doklady o tom, že zemřelí byli vybavováni vším, co potřebovali na dlouhou cestu, kterou museli podstoupit. To potvrzuje i zvyk dávat zemřelému pod jazyk peníz, kterým měl zemřelý zaplatil za převoz do Hádovy ř́še podsvětí. Mrtví byli pohřbíváni do pevně zbudovaných hrobů. Nalezly se i mrtvoly, které byly zatíženy kameny. Má se za to, že kameny měly bránit mrtvému v návratu na svět. Řekové, stejně jako později Rímané se snažili, aby hrůzu smrti zmírnili. U Homéra a v antických sousoších se smrt objevuje jako dvojče spánku nebo jako mladistvý okř́idlený Genius s vyhaslou pochodní. Rímané i Řekové již rozlišují mezi umíráním a smrtí. Slovem keer, popř. lethum se označuje umírání jednotlivého člověka. Pro smrt se používalo slovo thanatos nebo mors. Smrt byla v tomto období chápána jako něco pěkného, protože znamenala věčný klid a nepřítomnost vášní (Blumenthal-Baarby, 1987, s. 13).

\section{Řím}

Ř́mský polyhistor Plinius Starší (23-79) se ve svém díle Naturalis historia v knize VII. zamýšlí nad stárím i nad tím, jak člověk umírá, a opírá se při tom o Hippokrata. Plinius uvádí, že je také jeden druh nemoci, na níž lidé umírají, a to moudré odhodlání zemřít (Plinius Starší, 1973, kniha VII., s. 94). Uvádí pŕíklady představy št'astné smrti, což byla nenadálá smrt. „Úžasné jsou nenadálé smrti, většinou i časné, které jsou zcela přirozené, jsou vrcholným životním štěstím“ (Plinius Starší, 1973, kniha VII., s. 94). Na věčné otázky bytí či nebytí dávala vzdělanému Rímanovi odpověd' spíše filozofie než náboženství. Smrt nebyla pro Rímana vzdálenou, těžko představitelnou záhadou. Když odbila poslední hodina, bylo povinností pozůstalých postarat se o poslední poctu zesnulému. Cicero psal, že ve smrti mizí všechny majetkové rozdíly (Ürögdi, 1968, s. 247). Rodinní př́slušníci velmi dbali, aby podle nepsaných zákonů piety byly zachovány staré tradice náboženského původu. Umírajícího většinou položili na podlahu, aby měl $\mathrm{v}$ posledních okamžicích života prímý styk $\mathrm{s}$ matkou zemí, potom některý z blízkých příslušníků rodiny zachytil polibkem jeho poslední dech. Rodina pak několikrát opakovala jméno zesnulého (conclamatio). Přivolaní zřízenci pohřebního ústavu (pollinctores) omyli mrtvého teplou vodou, namazali vonnými oleji a mastmi, do úst mu vložili peníz pro převozníka podsvětí Charona, oblékli ho do slavnostního roucha (muže to tógy) a uložili na máry (lectus funebris). V soukromém domě se lectus funebris postavil do atria, ale at' to bylo ve vlastním, nebo pronajatém bytě, mrtvý musel vždy ležet nohama ke dveřím. Kolem lože stály kandelábry s olejovými kahanci, lucernami a svícemi. $\mathrm{Na}$ znamení smutku se dveře zdobily cyprrišovými ratolestmi a oheň v krbu se uhasil. I chudší lidé si většinou našetřili tolik peněz, aby se mohli stát členy pohřebního spolku (collegium funeraticium), který je pak za měsíční placené členské př́spěvky důstojně pochoval a postavil jim náhrobek. Pohřby obstarávali majitelé (libitarii) pohřebních ústavư a pohřeb měl propracovaný ceremoniál. Římané své mrtvé také spalovali a popel ukládali $\mathrm{v}$ mauzoleích podél velkých komunikací (Ürögdi, 1968, s. 247).

\section{Biblické pojetí umírání a smrti u židovského národa}

Umírání v biblickém pojetí je chápáno jako proces, při kterém se člověk vědomě přibližuje ke konci svého zemského života. Bible rozděluje umírající do dvou skupin:

- Lidé, kteří umírají ve hříchu, tedy stavu duchovního oddělení od Boha. Svưj konec vidí $\mathrm{v}$ hrobě a řídí se heslem ,Jezme pijme, stejně zítra umřeme“ - Kniha Izaiáš 22, 13 (Bible, 1985, s. 573). 
- Lidé, kteří umírají s vnitřním pokojem, jistotou a beze strachu. Ve Starém zákoně jsou zastoupeni především patriarchy.

V rodinách starozákonních patriarchů vznikla také tradice vědomé př́pravy na umírání a žehnání potomkům. Tento rituál se zachoval v celých dějinách Izraele a přešel pak i do křest'anských tradic novověku (Krrivohlavý a Kaczmarczyk, 1995, s. 83-86).

Pro smrt používá Starý zákon slovo MÁVET. Smrt není považována za konec, ale za oddělení vnitřního člověka od jeho tělesné schránky. Tělo bylo pro Židy vyjádřením osoby, ne jen zaměnitelné břímě pro úsek mezi dvěma zrozeními. Po smrti s ním proto Židé zacházeli $\mathrm{s}$ úctou, protože mělo být opět vzkříšeno. Zesnulý byl rituálně omýván a oblékán. Pohřbívání v jednotném pohřebním rouchu a bez rakve zavedli už ve starověku talmudičtí učenci a měla tím být vyjádřena rovnost všech lidí před Bohem. Pohřeb se konal co nejdříve po smrti, nejlépe ještě $\mathrm{v}$ den, kdy $\mathrm{k}$ úmrtí došlo. Proto se konaly i noční pohřby. Doprovodit zesnulého na poslední cestě bylo považováno za významný čin milosrdenství, protože zemřelý jej už nemohl oplatit (Halík, 2006, s. 96-97).

Nový fenomén, který zásadně ovlivňuje postoj $\mathrm{k}$ péči o umírající a ke smrti, přináší ve svém učení křest'anské náboženství na počátku našeho letopočtu. Je to zmírnění strachu ze smrti. V osobě Božího Syna, který na sebe bere vinu člověka a jako „dobrý Pastýřc doprovází ovečky na věčnost, dostává věřící jistotu, že nebude při svém umírání ani ve smrti opuštěn. Křest'anské pojetí nemoci a smrti přetrvalo až do dnešní doby. Neztotožňují se s ním jen věřící. I ti, kterým „víra nic neříká“, při setkání s umíráním, smrtí a v zármutku vděčně prijiímají zklidnění, které už staletí nabízí propracovaný řád církevních rituálů.

\section{Středověk}

Ve středověku byla smrt považována za něco přirozeného. Lidé se spíš báli náhlé smrti, protože vzala umírajícímu možnost rozloučit se a žádat o odpuštění hříchů. Hřbitovy a kostnice se staly veřejným místem ke schůzkám i hrám (Blumenthal-Barby, 1987, s. 15).

\section{Ars moriendi}

Ve 12. až 15. století se objevuje pojetí smrti jako „smrt - osobní konec“. Toto osobní a poslední drama jedince zobrazuje umění nazývané „ars moriendi“. Objevuje se jak v literatuře, tak v malírsství. V roce 1408 francouzský teolog Jean de Gerson dal svým textem De arte moriendi ( $\mathrm{O}$ umění umírat) podnět ke vzniku nejpopulárnějšího druhu literatury na sklonku středověku. Toto dílo se rychle rozšírílo po celé Francii a sloužilo jako podklad $\mathrm{k}$ výuce kněží i laiků pečujících o umírající. Nejproslulejší knihou o umírání v patnáctém století je kniha Ars moriendi der fünf Anfechtungen (Umění umírat při pěti pokušeních). Byla vytištěna mezi lety 1450 až 1460 a obsahovala jedenáct dřevorytů a třináctistránkový text. Oproti Gersonově knize jsou $\mathrm{v}$ ní všechna doporučení zaměřena na hodinu smrti a směrují zvláště $\mathrm{k}$ obraně proti pěti pokušením d'ábla (kolísání ve víře, netrpělivost, zoufalství, pýcha a lakomstvî). Nejdůležitější knihou pro umírající bylo Speculum artis bene moriendi (Zrcadlo umění správného umíránî), založené na uvedených vzorech, jež pocházelo od rektora vídeňské univerzity Nicolause von Dinkelsbuhl (asi 1360-1433). V českých zemích se podobné knihy objevují až v šestnáctém století, kdy s nástupem moru a krizí reformace se myšlenky na smrt a umírání dostávají do popředí. Jsou to např. Kniežky tyto slowú pŕíprawa $\mathrm{k}$ smrti od Pavla z Meziříčí (vydány roku 1507, 1520, 1556 a 1563) a různé překlady Manuále de praeparatione ad mortem (Př́ručka o př́pravě na smrt) od kazatele ve Zhořelci Martina Mollera (Schott, 1994, s. 115). Umírání a smrt se ve středověku stává námětem i pro umělce. Reakcí na šírící se smrt při morových epidemiích se stala zvláště zobrazení „tance smrti“" Zpodobnění smrti sloužilo jako memento mori (pamatuj na smrt), aby člověk nezapomněl na smrt, žil ctnostně životem a nezemřel ve hř́chu. Tanec kostlivců symbolizoval, že všichni si jsou před smrtí rovni. Představoval radu postav sestupného společenského postavení a mezi každou postavou byl kostlivec. Ve všech zobrazeních je smrt nakonec vítězem. Vrcholně ztvárnil motiv tance smrti ve svých dřevorytech Hans Holbein mladší (1497/981543). K nejznámějším $z$ těchto děl patří Obrazy smrti z roku 1526. Také německý malír a sochař Bernt Notke (1430/40-1509), který patřil $\mathrm{k}$ největším umělcům středověké severní Evropy, ztvárnil ve svých dílech tuto problematiku. Jeden z jeho nejznámějších obrazů „Tanec se smrti“ je v chrámu sv. Mikuláše v Tallinnu. 
Motiv tance smrti ožil později, i když v jiných souvislostech, v baroku a barokním umění (Schott, 1994, s. 136).

\section{Středověké morové epidemie}

Nedostatečná hygiena vedla zvláště ve městech k epidemiím. První morová epidemie v Evropě se rozšíríla za císaře Justiniána v letech 531-566; druhá vlna morové nákazy prrišla roku 1347 z Asie přes Orient do střední Evropy. Je známá také jako „černá smrt“. V období 1347-1352 zemřelo asi 25 milionů lidí, což bylo 25-30\% veškeré tehdejší populace (Schott, 1994, s. 64). Města se proti morové infekci bránila izolací lidí, kteří přicházeli z nakažených oblastí. V Benátkách byla délka izolace stanovena na čtyřricet dní, což se italsky řekne quaranta. Z tohoto výrazu bylo odvozeno slovo karanténa. Dalším opatřením bylo stanovení dohlížitelů, kteři vyhledávali domy, kde se vyskytl mor, a ty pak nechali biřici zapečetit, označit červeným kř́žem a hlídat dvěma hlídači ve dne i v noci. Z domu nesměl nikdo vyjít a hlídači sami zajišt'ovali potřebné věci (např. zavolání lékaře, donesení vody a potravin). Péče o nemocné spočívala v zajišt'ování základních potřeb a ochlazování prri vysokých horečkách. Pro nemocné byly zřizovány morové špitály, ale počet míst $\mathrm{v}$ nich byl zcela nedostačující vzhledem k počtu nakažených. Pokud někdo zemřel, byla povolána ohledávačka, která tělo zemřelého prohlédla a ohlásila to lékaři. Ranhojiči, kteří patřili $\mathrm{k}$ morovým špitálům, pomáhali ohledávačkám a společně prováděli prohlídku zemřelého. Pohřbívání zemřelých se konalo většinou $\mathrm{v}$ noci a nikdo z pŕibuzných nesměl doprovázet zesnulého (Mlýnková, 2006, s. 13-15).

\section{České země ve středověku}

$\mathrm{Ve}$ středověku byla úroveň péče o nemocné a umírající v Čechách srovnatelná s ostatními vyspělými zeměmi Evropy. Významnou osobností českých středověkých dějin byla $\mathrm{v}$ této oblasti Anežka Česká a Rytíŕský řád křržovníků s červenou hvězdou, který se věnoval špitální činnosti.

Anežka Česká (1207/1211?-1282) byla dcerou českého krále Přemysla Otakara I. a Konstancie Uherské. Můžeme ji považovat za zakladatelku organizované péče o nemocné a umírající v českých zemích. Anežka odmítla nabídku k sňatku císaře Friedricha II. (1194-
1250) a rozhodla se pro řeholní život a službu trpícím. V roce 1233 vybudovala v Praze první špitál v Českých zemích a založila laické špitální bratrstvo, které zajišt'ovalo péči o nemocné a umírající. Ve špitále byla nemocnice, chudobinec a útulek pro pocestné. Anežce se tak podařilo založit první sít' sociálních služeb. Organizace péče ve špitále byla na tehdejší dobu dokonalá a brzy se rozšíríla i do dalších českých měst, do Slezska a do Polska. Roku 1237 povýšil papež Řehoř IX. špitální bratrstvo na řád s řeholními pravidly. Hlavním posláním řádu byla špitální činnost. Vznikl tak Rytiřský řád křižovníků s červenou hvězdou (Jirásko, 1991, s. 35-36). Je to jediný rytířský řád založený ženou $\mathrm{v}$ historii celé katolické církve. Anežka vstoupila do kláštera a stala se abatyší (představenou). Obětavě sloužila potřebným, nemocným a umírajícím i mimo klášter. Získala si úctu a respekt celé středověké Evropy tím, že dokázala spojit královskou důstojnost $\mathrm{s}$ láskou k trpícím a péčí o nemocné a umírající. Zemřela v Praze 2. 3. 1282 (Kybal, 2001, s. 170-175). $\mathrm{V}$ roce 1989 byla papežem Janem Pavlem II. kanonizována.

Rozvoj péče o nemocné a umírající ve špitálech $\mathrm{v}$ českých zemích násilně ukončily husitské války - největší protifeudální a proticírkevní odboj v Evropě 15. století. Po husitských válkách většina špitálů zanikla a v řádu křižovníků převládla činnost pastorační nad původním charitativně-špitálním zaměřením. $V$ této podobě existuje řád i dnes. Současné hlavní sídlo velmistra Rádu je v Praze (Jirásko, 1991, s. 3536).

\section{Humanismus 18. století}

V 18. století se nemocný zobrazoval na smrtelném loži, jak s důvěrou hledí na své příbuzné. Současně se také nápadně změnila úloha těch, kteří se shromáždili okolo smrtelného lože. Nejsou to již pasivní a do modlitby pohroužené vedlejší postavy, ale jsou nyní přímo vtaženy do děje. Také mnoho humanistů 18 . století se ve svých pracích zabývá smrtí. Blumenthal-Barby (1987, s. 16) prípomíná práce Lessinga, Goetha i Schillera. V souvislosti s celoevropskou reformou zdravotnických systémů začaly v 18. století vznikat novodobé všeobecné nemocnice, které se orientovaly na léčení, ne na azylovou nebo terminální pomoc, a měly sloužit výhradně pacientům s akutním onemocněním. To dokazuje 
i výnos českého gubernia k otevření pražské Všeobecné nemocnice $\mathrm{v}$ roce 1791, ve kterém se píše, že z ošetřování jsou vyňati jen ti, kteří jsou stiženi dlouhotrvajícími a nezhojitelnými nemocemi, a jsou proto vhodní $\mathrm{k}$ prijetí do chorobince (Kalvach et al., 2004, s. 492). Mimo chorobinců vznikaly $\mathrm{v}$ té době i starobince a chudobince. Byly to předchůdkyně dnešních léčeben pro dlouhodobě nemocné a domovů pro seniory. Vojenskou obdobou chorobinců a starobinců byly $\mathrm{v} 18$. století invalidovny. O bezmocné a umírající se podle tzv. domovské prŕslušnosti, která byla podmíněna deseti lety pobytu v místě, ze zákona staraly domovské obce. Veřejné nemocnice nesměly prijímat chronicky nemocné, pacienty s tuberkulózním a onkologickým onemocněním, revmatiky, kardiaky, diabetiky apod. Těm zbývala jen domácí péče nebo péče vobecních chorobincích a chudobincích (Mášová, 2002, s. 40-44).

\section{9. století}

Ariès (2000b, s. 377-382) dochází na základě svých studií $\mathrm{k}$ závěru, že teprve až na počátku 19. století začíná smrt skutečně vzbuzovat úzkost. Tuto svou hypotézu dokazuje dochovanými popisy okolností smrti, testamenty a studiem množství dalších materiálů. To vše ho nakonec vedlo $\mathrm{k}$ přesvědčení, že smrt byla až do té doby pocit'ována jako něco všedního. Chybějící strach ze smrti však neznamenal, že by pozůstalí netruchlili za těmi, kteří odešli. Smutek se vyskytoval ve všech obdobích, i když intenzita byla různá. V 19. století se stávají výrazy smutku mnohem výraznější než dříve. Omdlévá se, drží se půst, chřadne se. Dř́ve rozptýlená citovost se nyní soustředila na několik vzácných bytostí. Tento model smrti dostává název „smrt blízkého" (Ariès, 2000b, s. 377). Pozůstalí přijímají smrt toho druhého obtížněji než dřive. Neobávají se tedy vlastní smrti, ale smrti druhého. Tento fenomén stojí na počátku zrodu moderního funerálního kultu hrobů a hřbitovů (Blumenthal-Barby, 1987, s. 16). Podoba křest’anských hřbitovů odrážela kulturní i sociální pluralitu soudobé křest'anské společnosti. Hřbitovy bývaly striktně konfesijně oddělené a př́značné bylo pohřbívání sebevrahů bez jména do hrobu za hřbitovní zdí (Davies, 2007, s. 122). V Čechách si jako projev protestu proti této praxi nenechal na hrob napsat svoje jméno chodský katolický kněz, buditel a spisovatel
Jindřich Šimon Baar (Halík, 2006, s. 98). Dnes i hřbitovy svědčí o postupu ekumenismu a tolerance mezi křest'any.

\section{Model domácího umírání}

Z generace na generaci přecházela zkušenost, jak pečovat o umírajícího doma, a každý znal vypracovaný rituál domácího umírání, který poskytoval oporu, nabízel útěchu a doprával pozůstalým prostor pro vyrovnání se smrtí. Umírající, který své poslední chvíle trávil v kruhu milovaných, sám poznal, že prrišla jeho „poslední hodinka“. Svolal všechny členy rodiny, řekl své poslední přání, nechal si zavolat kněze a prijal svátost nemocných (poslední pomazánî), se všemi se naposled rozloučil a v klidu zemřel. Lidé si přáli št'astnou smrt a věděli, jak by měla vypadat (Kutnohorská, 2007, s. 75-76).

Z 19. století pochází také starobylý zvyk spojený s domácím modelem umírání, tzv. stavění „umrlčích prken“, který se zachoval na Šumavě a v Bavorském lese až do konce 2. světové války. V zimním období, kdy zemřelí nemohli být pochováni na hřbitově pro velké množství sněhu, byli položeni na hladce oříznutá prkna a zůstávali ve sklepení domu až do doby, než roztál sníh. Potom byli pohřbeni na hřbitově. Prkna byla ozdobena řezbami, malbami a byl na nich umístěn štítek se jménem, vlastnostmi a majetkem zemřelého. Prkna bývala umístěna na rozcestí nebo u statků a měla ochranný a symbolický význam pro pozůstalé. Tato prkna můžeme ještě dnes vidět $\mathrm{v}$ kapli u Železné Rudy a jsou také součástí sbírky funerálních předmětů Muzea Šumavy v Kašperských Horách (Anděra, Zavřel et al., 2003, s. 527529). Podobná sbírka se nachází i v muzeu u benediktinského kláštera Melk v sousedním Rakousku.

\section{Komercionalizace smrti}

Koncem 19. století se ve vztahu ke smrti objevuje nový fenomén, kterým je komercionalizace smrti. Tento jev se poprvé objevuje ve Spojených státech amerických a není vyloučeno, že právě tento fenomén ovlivnil Evropu a tím i současné postoje ke smrti. Hřbitovy, které byly v USA veřejným vlastnictvím, přešly do oblasti soukromého podnikání. Výrobci rakví, hrobníci i vlastníci povozů se stali podnikateli a smrt se stala obchodem. Pohřby a hřbitovy se prezento- 
valy v reklamách stejně jako jakékoliv jiné zboží, od co nejpřirozenější úpravy těla zemřelého až k vyřízení všech potřebných formalit (Blumenthal-Barby, 1987, s. 16-17).

\section{0. století a institucionalizace terminální péče}

S rozvojem urbanizace se umírání pozvolna přemíst'ovalo do nemocnic. Model, kdy umírající byl až do své poslední hodiny v domácím prostředí, se postupně vytrácel. Zodpovědnost, kterou až do středověku měl umírající sám a později stále více jeho rodina, přechází na zcela anonymní okruh lidí - na personál nemocnice. $Z$ toho vyplývá změněný postoj $\mathrm{k}$ umírání a smrti. Ve snaze zlepšit situaci umírajícího i ostatních, kteří měli být uchráněni pohledu na umírání neznámého člověka, vznikla praxe tzv. bílé zástěny - plenty. Ta se začala běžně používat na počátku 20. století a měla umírajícímu zajistit klid a spolupacienty ušetřit pohledů na umírajícího (Haškovcová, 2007, s. 30). S praxí „bílé zástěny" se setkáváme i v dnešních nemocnicích. Později byl pro umírající vyčleňován zvláštní pokoj. Tato praxe měla negativní psychický dopad nejen na umírajícího, ale i na ostatní spolupacienty a v dnešní době se s ní už nesetkáváme. Také omezené návštěvní hodiny měly na pacienta velmi negativní vliv. A tak se často stávalo, že umírající byl sice obklopen profesionální péčí anonymních osob, ale při umírání byl sám a opuštěný. Je velkým úkolem všech zdravotníků dokázat vytvořit nový ritualizovaný model důstojného umírání v podmínkách institucionální péče.

\section{Současné postoje ke smrti}

$\mathrm{V}$ dnešní době se nesetkáváme s jedním univerzálním rámcem umírání. Vedle sebe existuje více modelů postoje $\mathrm{k}$ umírání. Můžeme se setkat s modely postoje ke smrti, které Viewegh (1981, s. 16-20) označil termíny: smrt jako tabu, smrt jako samota a smrt jako dovršení.

\section{Smrt jako tabu}

Umírání a smrt je z hlediska individuálního lidského života násilným ukončením a přetržením všeho, s čím se člověk důvěrně sžil. Proto není pro lidského jedince smrt pouhým přechodem z bytí do nebytí, ale skokem do prázdna (Viewegh, 1981, s.17). Téma smrti je v naší civilizaci tabu. Lidé se instinktivně vyhýbají každé zmínce o smrti i umírání, protože jim to připomíná vlastní smrt. Vědomí smrti narušuje člověku i jeho hierarchii hodnot, kterými se ve svém životě rrídí. Dalším zdrojem úzkosti ze smrti je fakt, že smrt nemůžeme hlouběji analyzovat, protože je mimo naši smyslovou zkušenost. Fenomén tabuizované smrti, jak připomíná Haškovcová (2007, s. 22), se stal obecným jevem zejména $\mathrm{v}$ době po druhé světové válce. Lidé, kteř́ přežili válečné hrůzy a smrt milionů nevinných lidí, už nechtěli slyšet o smrti. Upínali všechnu svou naději ke všemocné medicíně, která je schopná zvítězit nad každou nemocí. A tak se o smrti mlčelo, jako kdyby přestala existovat.

\section{Smrt jako samota}

Důsledkem tabuizace smrti je osamělost umírajícího člověka. $V$ dnešní době se umírá většinou ve zdravotnickém nebo sociálním zařízení, v neznámém prostředí a mezi neznámými lidmi. Pohled na umírajícího člověka je pro zdravotníky podvědomě traumatizující, proto zkracují instinktivně dobu svého pobytu u něj na minimum. Umírající člověk je tak postupně vyloučen z komunikace s ostatními lidmi, je izolován, zapomenut. V posledních letech se tento fenomén označuje také jako „sociální smrt“. Problém sociální smrti patři do širšího tematického okruhu tzv. psychologie smrti, která především studuje chování lidí $\mathrm{k}$ sobě navzájem $\mathrm{v}$ nějaké situaci, která připomíná smrt (Viewegh, 1981, s. 18).

\section{Smrt jako dovršení}

Podle toho, jaký má člověk názor na smrt, jak se na svoji smrt dívá, prožívá také umírání. Existují lidé, kteří umírají s vnitřním pokojem, jistotou a beze strachu. Bůh, s kterým žijí v osobním společenství, je pro ně zdrojem jistoty, že $\mathrm{s}$ nimi bude i v hodinách umírání a odchodu duše $z$ těla. Mají před sebou jasnou vizi, že tělesná smrt je přechodem do nebeského domova. Jejich víra jim pomáhá a vede je ke statečnosti a naději. Tento postoj ovlivňuje nejen umírajícího, ale i zdravotnický personál. Podobně mohou umírat i lidé, kteří podle svého přesvědčení žili pro velké ideály a bojovali za tzv. „smělé cíle“ - i když nebyli věřící. Musíme si ale připustit, že jen málo lidí dostane šanci prožít svou smrt jako důstojné dovršení života. 


\section{Zakázaná smrt}

$\mathrm{V}$ dnešní době touží člověk po rychlé a bezbolestné smrti, aby se vyhnul útrapám dlouhého bolestného umírání a osamělosti. Ariès mluví v této souvislosti o „zakázané smrti“. Smrt, která byla dříve tak důvěrně známá a lidé si její prítomnost uvědomovali, se najednou jakoby ztrácí $\mathrm{v}$ nemocnici a stává se něčím cizím, neznámým, obávaným. $\mathrm{Na}$ rozdíl od středověku si dnes člověk přeje náhlou smrt, aby se vyhnul útrapám bolestného umírání. Jak připomíná Ariès tento př́stup však neodstranil ze světa ani smrt, ani strach a úzkost ze smrti. Naopak, umožnil „potměšilý návrat staré divokosti smrti“ pod maskou lékařské techniky (Ariès, 2000b, s. 382).

Právo na smrt bývá v současnosti interpretováno jako právo na důstojnou smrt. Obsah tohoto pojmu není zatím zcela ustálený. Ve světě byla založena řada společností, které se touto problematikou zabývají a hledají možnosti, jak učinit odchod člověka $z$ tohoto světa důstojný. Většina společností pro důstojné umírání se jednoznačně shoduje $\mathrm{v}$ tom, že stávající proces institucionalizovaného umírání musí projít kvalitativní změnou a je potřeba vhodně implementovat tradice ritualizované péče o umírající do stávajícího systému zdravotní a sociální péče.

\section{ZÁVĚR}

Důstojnost umírání je velmi složitá entita, která má svůj filozofický, společenský i historický rozměr. Ke konci 20. a počátkem 21. století se hovoři o „odlidštění“ umírání. Člověku je poskytnuta péče prostřednictvím techniky a nových technologií. Hledá se novodobý rituál umírání, kde hlavní pomoc by poskytl blízký člověk, který by pomohl smysluplně uzavřít životní příběh každého umírajícího člověka. Seznámení se s tradicí, tj. také s tím, jak lidé umírali $\mathrm{v}$ minulosti, patř́ $\mathrm{k}$ základům, na nichž stojí mravní principy současné společnosti. Každý zdravotník, který je v kontaktu se smrtí, by měl vědět, jak lidé v minulosti umírali. Smyslem všech rituálů je znát průběh dané události. Ví- me, jak probíhá křest, svatba, promoce atd. Chtěli bychom vědět, jak budeme umírat.

\section{LITERATURA}

ABDEL-KHALEK, A., TOMÁS-SÁBADO, J.: Anxiety and Death Anxiety in Egyptian and Spanish Nursing Students. Death Studies, Routlege: T\&F 2005, vol. 29, no 2, s. 157-167.

ANDĚRA, M., ZAVŘEL. P. et al.: Šumava, 1. vyd. Praha: Baset, 2003, s. 527-529.

ARIĖS, P.: Dějiny smrti. Díl 2. Zdivočelá smrt. 1. vyd. Praha: Argo, 2000b, s. 370-393.

BIBLE, Český ekumenický překlad, 1. vyd. Praha: Česká biblická společnost, 1985, s. 573.

BLUMENTHAL-BARBY, K. et al.: Kapitoly $z$ thanatologie. 1. vyd. Praha: Avicenum, 1987, s. 12-17.

DAVIES, D. J.: Stručné dějiny smrti. 1. vyd. Praha: VOLVOX GLOBATOR, 2007, s. 122.

HALÍK, T.: Prolínání světů. 1. vyd. Praha: Nakladatelství Lidové noviny, 2006, s. 96-97.

HAŠKOVCOVÁ, H.: Thanatologie - Nauka o umírání a smrti. 2. vyd. Praha: Galén, 2007, s. 30.

HERODOTÓS: Dějiny. 2. vyd. Praha: Odeon, 1972, s. $73,127-128,245-247$.

JIRÁSKO, L.: Církevní rády a kongregace $v$ zemích českých. 1. vyd. Praha: Strahov, 1991, s. 35-36.

KALVACH, Z., ZADÁK, Z., JIRÁK, R. et al.: Geriatrie a gerontologie. 1. vyd. Praha: Grada, 2004, s. 492.

KLÍMA, O.: Sláva a pád starého Íránu. 1. vyd. Praha: Orbis, 1977, s. 29-30.

KŘIVOHLAVÝ, J., KACZMARCZYK, S.: Poslední úsek cesty. 1. vyd. Praha: Návrat domů, 1995, s. 83-86.

KUTNOHORSKÁ, J.: Etika $v$ ošetrovatelství. 1. vyd. Praha: Grada, 2007, s. 75-76.

KYBAL, V.: Svatá Anežka Česká. 1. vyd. Brno: L. Marek, 2001, s. 170-175.

LALOUETTOVÁ, C.: Egypt. Králové starověkého Egypta. 1. vyd. Praha: Levné knihy, 2009, s. 12-13, 203.

MÁŠOVÁ, H.: Thomayerova nemocnice v Praze - někdejší Masarykovy domovy. Sanquis, Praha: WALD Press 2002, vol. 4, no 20, s. 40-44.

MLÝNKOVÁ, J.: Péče o nemocné $\mathrm{v}$ době středověkých epidemií. Florence, Praha: Galén 2006, vol. 2, no 9 , s. 13-15.

PLINIUS STARŠÍ.: Kapitoly o př́rodě. Praha: Svoboda. Antická knihovna, 1973, sv. 19, s. 94.

SCHOTT, H.: Kronika medicíny. 1. vyd. Praha: Fortuna Print, 1994, s. 64, 115 a 136.

SMIRNOV, A. P.: Skytové, 1. vyd. Praha: Panaroma, 1980, s. 7-8

ÜRÖGDI, G.: Tak žil starý Ř́m. 1. vyd. Praha: Orbis, 1968, s. 247.

VIEWEGH, J.: Psychologická hlediska péče o dlouhodobě nemocné a umírající. 1. vyd. Brno: UDVSZP, 1981, s. $16-20$.

\section{Helena Kisvetrová, Jana Kutnohorská} helena.kisvetrova@upol.cz 